\title{
CaO- $\mathrm{P}_{2} \mathrm{O}_{5}$ glass hydroxyapatite double-layer plasma-sprayed coating: In vitro bioactivity evaluation
}

\author{
M. P. Ferraz, ${ }^{1,2}$ F. J. Monteiro, ${ }^{1,2}$ J. D. Santos ${ }^{1,2}$ \\ ${ }^{1}$ Departamento de Engenharia Metalúrgica, FEUP, Universidade do Porto, R. dos Bragas, 4099 Porto Codex, Portugal \\ ${ }^{2}$ INEB-Instituto de Engenharia Biomédica, Rua do Campo Alegre, 823, 4150 Porto, Portugal
}

Received 22 September 1997; accepted 17 December 1998

\begin{abstract}
Double-layer composite coatings composed of a $\mathrm{P}_{2} \mathrm{O}_{5}$-based glass $/ \mathrm{Ca}_{10}\left(\mathrm{PO}_{4}\right)_{6}(\mathrm{OH})_{2}(\mathrm{HA})$ mixture top layer and a simple HA underlayer, on Ti-6AI-4V substrates, were prepared using a plasma-spraying technique. The in vitro bioactivity of these coatings was assessed by immersion testing in simulated body fluid. Both scanning electron microscopy (SEM) analysis and the ionic solution changes followed by atomic absorption spectroscopy and the molybdenum blue method demonstrated that these composite coatings induce a faster surface Ca-P layer formation than the simple
\end{abstract}

HA coatings used as a control. X-ray photoelectron spectroscopy (XPS) analysis demonstrated that the Ca-P layer formed was apatite. The combination of SEM and XPS analyses showed that the apatite layer was a calciumdeficient hydroxyapatite with a $\mathrm{Ca} / \mathrm{P}$ ranging from 1.3 to 1.4 with $\mathrm{CO}_{3}{ }^{2-}$ groups contained in the structure. (C) 1999 John Wiley \& Sons, Inc. J Biomed Mater Res, 45, 376-383, 1999.

Key words: double-layer coatings; hydroxyapatite; glass; plasma spraying; bioactivity

\section{INTRODUCTION}

Considerable attention has been paid to hydroxyapatite (HA), $\mathrm{Ca}_{10}\left(\mathrm{PO}_{4}\right)_{6}(\mathrm{OH})_{2}$, as a tissue replacement material for use both in dentristy and orthopedics. ${ }^{1,2}$ However, human bone mineral is quite different from conventional stoichiometric HA in terms of chemical composition, as it contains other ions such as potassium, magnesium, carbonate, fluoride, and sodium. Some recent work has been directed toward incorporating these ions into the HA lattice ${ }^{3,4}$ to more closely match the composition of human bone mineral, thereby improving the biological response of the implant materials.

Bioactive coatings on metallic implants are associated with disadvantages such as prosthesis loosening, with metal accumulation in surrounding tissue. This has led to the need to find alternatives aimed at providing implants with bioactive coatings which would be better tolerated, interacting with the host tissues, slowly dissolving in a controlled fashion, and allowing bone growth to take place at interstitial sites on the surface $^{5-7}$ The coatings may be produced by plasma spraying, which involves the formation of a stream of

Correspondence to: J. D. Santos

Contract grant sponsor: JNICT; Contract grant numbers: PBICT "Novos revestimentos bioactivos obtidos por projecção por plasma" 1990/95, Praxis XXI/BD/9716/96

(c) 1999 John Wiley \& Sons, Inc.

CCC 0021-9304/99/040376-08 molten particles produced by injecting a powder into a high-velocity, high-temperature plasma jet and firing them at a substrate. The coating is formed by successive impact of molten particles on the substrate spreading to form disc-shaped lamella. ${ }^{8,9}$

One early solution which appeared to stand a good chance, apparently showing good biological tolerance, consisted of HA-coated Ti alloy implants. ${ }^{10,11}$ The similarity in composition between HA and bone mineral means that the implant was not recognized as a foreign material, which allowed for continuous bone growth through the surface holes and concavities of the coating. However HA's bioactivity is very limited, and thus osseointegration is too slow, leading to longterm immobilization periods for the patient. The use of bioactive glasses as coated layers could be an alternative, but they show too fast a rate of biodegradation, leading to rapid resorption after surgery. Besides showing adequate chemical and structural matching, such materials require appropriate surface characteristics: namely, pore connectivity, distribution, and size, so that adequate bone bonding might be achieved.

In the present work, bioactive multilayered coatings were prepared consisting of consecutive plasmasprayed layers of variable composition, the layer next to the substrate being composed of HA, and the top layer composed of HA plus bioactive glass composite. This kind of coating is expected to induce a rapid ini- 
TABLE I

Chemical Composition of $\mathrm{P}_{2} \mathrm{O}_{5}$-Based Glass ( $\mathrm{mol} \%$ )

\begin{tabular}{ccccc}
\hline & $\mathrm{P}_{2} \mathrm{O}_{5}$ & $\mathrm{CaO}$ & $\mathrm{Na}_{2} \mathrm{O}$ & $\mathrm{K}_{2} \mathrm{O}$ \\
\hline $\mathrm{G} 1$ & 35.0 & 35.0 & 20.0 & 10.0 \\
\hline
\end{tabular}

tial response, due to the presence of bioactive glasses, followed by a more stable period, due to the HA underlayer which allows for adequate consolidation, as strong bonding occurs with the grown surrounding bone tissue.

In bone tissues, the exact composition and relative proportions of collagen fibers, mineral, and noncollageneous proteins, depend upon the location and loading requirements of bone. ${ }^{12-14}$ The chemical analysis of the inorganic part of bone is complex because of ion substitution that may occur in hydroxyapatite lattice, where $\mathrm{CO}_{3}{ }^{2-}$ is a common substitute for $\mathrm{OH}^{-}$or $\mathrm{PO}_{4}{ }^{3-}, \mathrm{Mg}^{2+}$, and $\mathrm{Na}^{+}$for $\mathrm{Ca}^{2+}$, and $\mathrm{F}^{-}$for $\mathrm{OH}^{-}$. Therefore, there is a need to include these trace elements in the HA used for implants and prostheses, since the biological behavior of apatites is strongly dependent on their composition. ${ }^{15}$

Using glasses within the $\mathrm{P}_{2} \mathrm{O}_{5}-\mathrm{CaO}$ system with additions of $\mathrm{Na}^{+}, \mathrm{Mg}^{2+}$, and $\mathrm{K}^{+}$ions, glass-reinforced $\mathrm{HA}$ composites can be prepared by a liquid-phase sintering process, with much higher biaxial bending strength than commercial sintered HA. ${ }^{16}$ In addition, the nominal elemental percentages of $\mathrm{Na}^{+}, \mathrm{Mg}^{2+}$, and $\mathrm{K}^{+}$in the composites prepared in this work are similar to those found in bone tissues.

Kokubo et al. showed that a thin layer of biological apatite was formed on the surface of bioactive ceramic materials in a simulated body fluid (SBF). ${ }^{17}$ The bioactivity of orthopedic biomaterials has been attributed to the ability of their surfaces to nucleate carbonate apatite crystals very similar to bone crystals from supersaturated body fluids. ${ }^{18-21}$ In the case of bioglasses and some other biomaterials, the events preceding the formation of the newly formed apatite layer have been described in detail in the literature. ${ }^{18}$ For calcium phosphate coatings, however, such studies have not yet been performed and the possible surface modifications, as well as their consequence on the formation of the crystal layer from body fluids, are largely unknown. ${ }^{22}$ The chemical reactions occurring on the coating surfaces play an important role in the bonding mechanism. ${ }^{23,24}$ Since the ceramic surface initially reacts with surrounding extracellular fluid, the nature of the solids formed on the surface is determined by the crystal chemistry of the ceramic and the chemical composition of the fluid. ${ }^{25}$

In this study, to evaluate the surface reactions of double-layered coatings, three types of coatings (HA, $\mathrm{HA} / \mathrm{G}_{1} 2 \%$ composite, and $\mathrm{HA} / \mathrm{G}_{1} 4 \%$ composite) were exposed to an SBF. Changes in the ionic solutions were examined by measurement of total $\mathrm{Ca}, \mathrm{P}, \mathrm{Mg}$, $\mathrm{Na}$, and $\mathrm{K}$ concentration. The natural apatite film formation and its chemical composition were followed by scanning electron microscopy (SEM) and X-ray photoelectron spectroscopy (XPS).

\section{MATERIALS AND METHODS}

\section{Materials preparation}

A $\mathrm{P}_{2} \mathrm{O}_{5}$-based glass (G1), with the chemical composition listed in Table I, was prepared from reagent-grade chemicals. The composite preparation method has been fully described elsewhere. ${ }^{26}$ Glass additions of $2 \mathrm{wt} \%$ and $4 \mathrm{wt} \%$ to HA were used.

Mixed powders were then dried, isostatically pressed at $200 \mathrm{MPa}$, and sintered. Samples were than milled and sieved to provide a particle size distribution between 53 and $150 \mu \mathrm{m}$.

Titanium alloy disks (Ti-6Al-4V) $14 \mathrm{~mm}$ in diameter and 3 mm thick were coated using plasma-spraying employing HA and composite powders according to the above granulometric distribution. An atmospheric plasma-spraying technique was performed on Plasma Technik automated equipment, and all substrates were coated at the same time to ensure the same coating thickness for all samples. Coating thickness was determined by micrometer measurement. Three types of coatings were prepared as shown in Table II.

\section{SBF immersion testing}

Simulated body fluid with inorganic ion concentrations close to those found in human blood plasma, as shown in Table III, was prepared by dissolving reagent-grade chemicals in distilled water, buffered at $\mathrm{pH} 7.25$, at $37^{\circ} \mathrm{C}$ with

TABLE II

Coating Composition (wt \%) and Thickness ( $\mu \mathrm{m})$

\begin{tabular}{lcccc}
\hline \multirow{2}{*}{ Sample } & \multicolumn{2}{c}{ Composition $(w t \%)$} & \multicolumn{2}{c}{ Coating thickness $(\mu \mathrm{m})$} \\
\cline { 2 - 4 } & First Layer & Second Layer & First Layer & 120 \\
\hline HA & HA & & 60 & Second Layer \\
Composite HA $/ \mathrm{G}_{1} 2 \%$ & $\mathrm{HA}$ & $98 \% \mathrm{HA}+2 \% \mathrm{G} 1$ & 60 & 60 \\
Composite HA $/ \mathrm{G}_{1} 4 \%$ & $\mathrm{HA}$ & $96 \% \mathrm{HA}+4 \% \mathrm{G} 1$ & 60 \\
\hline
\end{tabular}


TABLE III

Ion Concentrations of SBF and Human Blood Plasma (mM)

\begin{tabular}{lllllllrr}
\hline \multirow{2}{*}{ Solution } & \multicolumn{7}{c}{ Concentration $(\mathrm{mM})$} \\
\cline { 2 - 8 } & $\mathrm{Na}^{+}$ & $\mathrm{K}^{+}$ & $\mathrm{Ca}^{2+}$ & $\mathrm{Mg}^{2+}$ & $\mathrm{HCO}_{3}^{-}$ & $\mathrm{Cl}^{-}$ & $\mathrm{HPO}_{4}^{2-}$ & $\mathrm{SO}_{4}^{2-}$ \\
\hline Blood plasma & 142.0 & 5.0 & 2.5 & 1.5 & 27.0 & 103.0 & 1.0 \\
SBF & 142.0 & 5.0 & 2.5 & 1.5 & 4.2 & 148.0 & 1.0 & 0.5 \\
\hline
\end{tabular}

tris(hydroxymethyl) aminomethane $\left(\left[\mathrm{CH}_{2} \mathrm{OH}\right]_{3} \mathrm{CNH}_{2}\right)$ and $1 \mathrm{M}$ hydrochloric acid $(\mathrm{HCl}){ }^{27}$

Duplicate specimens of each type of coating were placed in $100-\mathrm{cm}^{3}$ polyethylene flasks with $50 \mathrm{~cm}^{3}$ of solution. The flasks were sealed to minimize changes in the initial $\mathrm{pH}$. All immersions took place at $37^{\circ} \mathrm{C}$ without stirring, in a $5 \% \mathrm{CO}_{2}$ atmosphere. The blank control was done with exactly the same experimental conditions, in the absence of materials. After several exposure periods, the specimens were removed, rinsed in distilled water, and dried in air, and the solution changes were evaluated by measurements of total $\mathrm{Ca}, \mathrm{Mg}, \mathrm{Na}, \mathrm{K}$, and $\mathrm{P}$. The concentration of $\mathrm{Ca}, \mathrm{Mg}$, $\mathrm{Na}$, and $\mathrm{K}$ was determined by atomic absorption spectroscopy, and of $\mathrm{P}$, by the molybdenum blue method. ${ }^{25}$ The results are shown as the arithmetic mean and standard deviation $( \pm S D)$. Statistical analysis of the experimental results was performed using Tukey-HSD and $t$ tests, with a significance level of $p<.05$.

\section{Film formation and characterization}

Surfaces were sputter-coated with a thin layer of carbon and observed by SEM, using a Jeol JSM 35-C microscope equipped with a Noran Instruments energy-dispersive spectroscope (EDS). By using sequential observation, the time required for surface film formation was estimated.

\section{Chemical analysis of surface film}

Samples surfaces that showed a full coverage of new crystals when observed by SEM were later analyzed using XPS to ensure that this analysis was exclusively performed on the apatite film, without interference. The XPS analyses were performed on a VG spectrometer using $\mathrm{MgK} \alpha$ radiation and $50-\mathrm{eV}$ analyzer pass energy. The analysis of nonconductive samples is always associated with a band shift owing to the charge accumulation on the surface. The peak of aliphatic carbon contaminants (285.0-eV binding energy), always present on any sample, was chosen as a reference for the correction of peak position. The relative atomic concentrations were determined based on C1s, O1s, P2p, Ca2p3, Na1s, and $\mathrm{Mg} 2 \mathrm{p}$ peaks, using the sensitivity factors given by Scofield. The peaks were fitted using the installed software.

\section{RESULTS}

\section{Solution changes}

$\mathrm{Ca}^{2+}$ concentration

Figure 1 shows the variations in $\mathrm{Ca}^{2+}$ concentration in SBF with immersion time for $\mathrm{HA}, \mathrm{HA} / \mathrm{G}_{1} 2 \%$, and
$\mathrm{HA} / \mathrm{G}_{1} 4 \%$ composite samples. $\mathrm{Ca}^{2+}$ ions in the solution decreased with immersion time, indicating that these ions were accumulated on the surface of the coatings. More important, a faster rate of deposition occurred on the composite coatings surfaces than onto pure HA coatings. Furthermore, the higher percentage of G1 glass favored a higher deposition of $\mathrm{Ca}^{2+}$ ions. After 1 day of immersion, all $\mathrm{C}_{\mathrm{t}}-\mathrm{C}_{0}$ values of $\mathrm{Ca}^{2+}$ for $\mathrm{HA} / \mathrm{G}_{1} 4 \%$ composite were statistically different from those of HA $(p<.05)$. The same behavior was found for $\mathrm{HA} / \mathrm{G}_{1} 2 \%$ composite after 5 days of immersion. On the blank control, the $\mathrm{Ca}^{2+}$ concentration was kept constant and equal to the initial one $\left(C_{\mathrm{o}}\right)$. These results were confirmed by SEM observations, as will be presented later.

$\mathrm{PO}_{4}{ }^{3-}$ concentration

Figure 2 shows the variation in $\mathrm{PO}_{4}{ }^{3-}$ concentration in SBF with immersion time for $\mathrm{HA}, \mathrm{HA} / \mathrm{G}_{1} 2 \%$, and $\mathrm{HA} / \mathrm{G}_{1} 4 \%$ composite samples. $\mathrm{PO}_{4}{ }^{3-}$ concentration followed a tendency similar to that of $\mathrm{Ca}^{2+}$ ions: After a certain initial incubation period, there was a decrease in concentration with immersion time which was more pronounced for the composite coatings than for the HA coatings. After 1 day of immersion, all

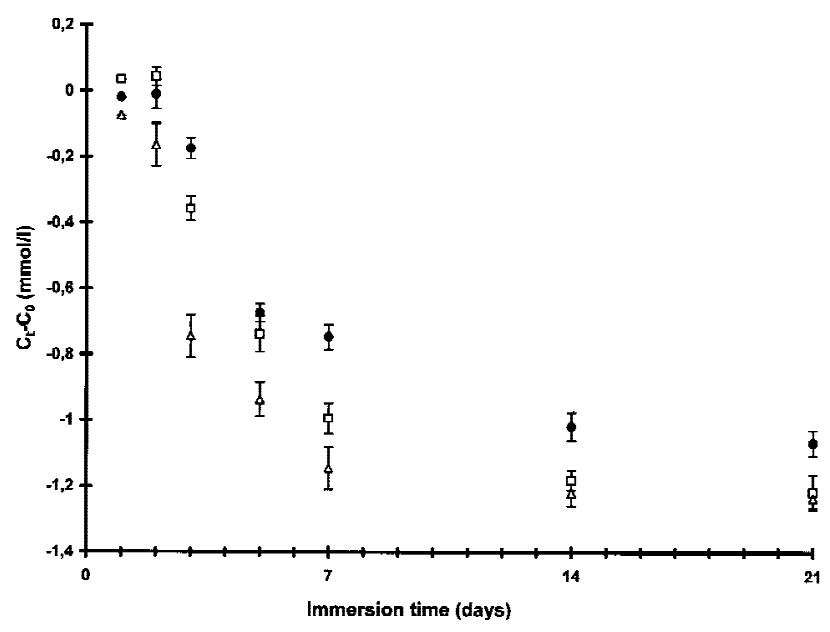

Figure 1. Concentration versus immersion time plots of $\mathrm{Ca}^{2+}$ in solution after immersion of $\mathrm{HA}(\bullet), \mathrm{HA} / \mathrm{G}_{1} 2 \%(\square)$, and $\mathrm{HA} / \mathrm{G}_{1} 4 \%(\triangle)$ composite coatings. $\mathrm{C}_{\mathrm{t}}-\mathrm{C}_{0}=$ change in concentration from the initial $\left(C_{0}\right)$ value; error bars stand for SD. 


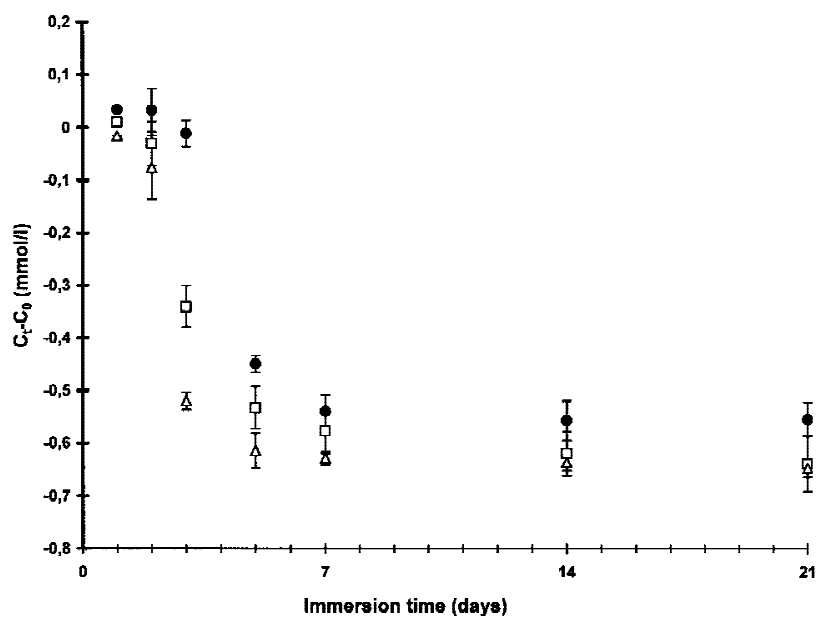

Figure 2. Concentration versus immersion time plots of $\mathrm{PO}_{4}{ }^{3-}$ in solution after immersion of $\mathrm{HA}(\mathbf{)}), \mathrm{HA} / \mathrm{G}_{1} 2 \%(\square)$, and $\mathrm{HA} / \mathrm{G}_{1} 4 \%(\triangle)$ composite coatings. $\mathrm{C}_{\mathrm{t}}-\mathrm{C}_{0}=$ change in concentration from the initial $\left(\mathrm{C}_{0}\right)$ value; error bars stand for SD.

$\mathrm{C}_{\mathrm{t}}-\mathrm{C}_{0}$ values of $\mathrm{PO}_{4}{ }^{3-}$ for the $\mathrm{HA} / \mathrm{G}_{1} 4 \%$ composite were statistically different from those of HA $(p<.05)$. A similar tendency was observed for the $\mathrm{HA} / \mathrm{G}_{1} 2 \%$ composite. On the blank control, the $\mathrm{PO}_{4}{ }^{3-}$ concentration was kept constant and equal to the initial one $\left(\mathrm{C}_{\mathrm{o}}\right)$.

$\mathrm{K}^{+}, \mathrm{Na}^{+}$, and $\mathrm{Mg}^{2+}$ concentration

$\mathrm{K}^{+}, \mathrm{Na}^{+}$and $\mathrm{Mg}^{2+}$ concentrations in the SBF solution remained unchanged with immersion time for the three coatings and the blank control. This behavior indicates that the formed film was mainly composed of $\mathrm{Ca}^{2+}$ and $\mathrm{PO}_{4}{ }^{3-}$, as demonstrated by XPS analysis.

\section{Surface changes and surface film formation rate}

Figure 3 shows a typical surface of a plasmasprayed HA coating before immersion in SBF. Similar morphologies were obtained for the other two coatings: $\mathrm{HA} / \mathrm{G}_{1} 2 \%$ and $\mathrm{HA} / \mathrm{G}_{1} \%$ composites. After 7 days' immersion, calcium phosphate crystals could be detected on the surface of $\mathrm{HA}$ and $\mathrm{HA} / \mathrm{G}_{1} 2 \%$, as may be observed in Figure $4(a, b)$, respectively. Similarly, for the same immersion period, the surface of HA/ $\mathrm{G}_{1} 4 \%$ composite was already fully covered with a calcium phosphate film [Fig. 4(c)]. Increasing the immersion time in SBF to 14 days led to an increase in the proliferation of calcium phosphate crystals and to complete coverage of the surface of both $\mathrm{HA} / \mathrm{G}_{1} 2 \%$ and $\mathrm{HA} / \mathrm{G}_{1} 4 \%$ composites, while some areas remained uncovered for the HA coating, as presented in
Figure 5. Complete coverage of the HA coating surface was only achieved after 21 days' immersion.

This behavior was in agreement with the $\mathrm{Ca}$ and $\mathrm{PO}_{4}{ }^{3-}$ ionic depletion detected in the SBF solution and showed that there was a clear tendency for faster calcium phosphate formation on the surface of composite coatings than on the HA coatings.

\section{Chemical analysis of surface film}

X-ray photoelectron spectroscopy analysis of the elements present on the surface of HA and composite coatings were recorded after 7 days, 14 days, and 2 months of immersion. Ca2p3-, P2p-, O1s-, and C1slevel spectra were identified. Additional peaks for Na1s were also found, particularly after 2 weeks' immersion. The peak position of elements detected on the surface and their relative concentration are presented in Tables IV and V. The chemical composition of the surface layer formed seemed to be independent of the composition of the material. Furthermore, no significant changes in the $\mathrm{Ca} / \mathrm{P}$ ratio of the layers seemed to have occurred with immersion time, although the proportion of $\mathrm{Ca}$ and $\mathrm{P}$ in the layer tended to decrease with immersion time and the proportion of $C$ appeared to increase.

Since the C1s peaks were very broad and intense after immersion, they were deconvoluted using a Gaussian curve-fitting process. The deconvoluted peaks revealed that each C1s peak was composed of two peaks: one at $285.0 \pm 0.1 \mathrm{eV}$ and another at approximately $287.8 \pm 0.1 \mathrm{eV}$ (Fig. 6).

\section{DISCUSSION}

Several authors have reported that calcium phosphate formation on a material's surface in simulated

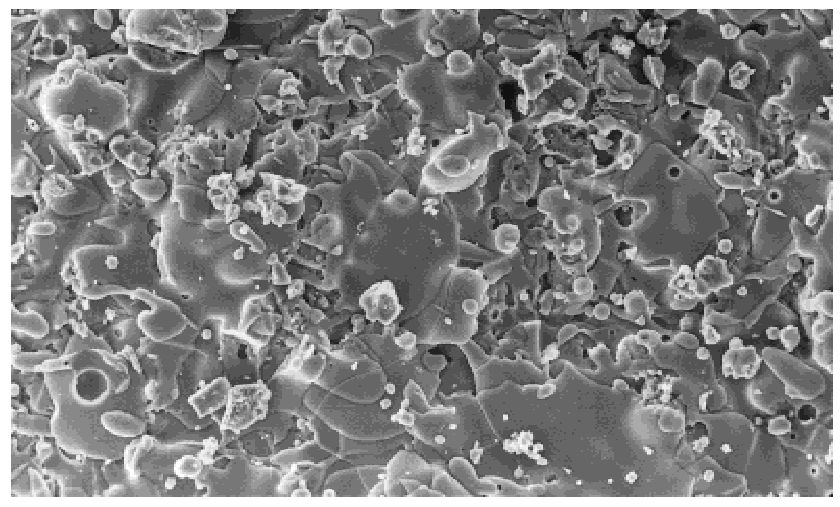

Figure 3. Surface of a plasma-sprayed HA coating (original magnification, $\times 500$ ). 


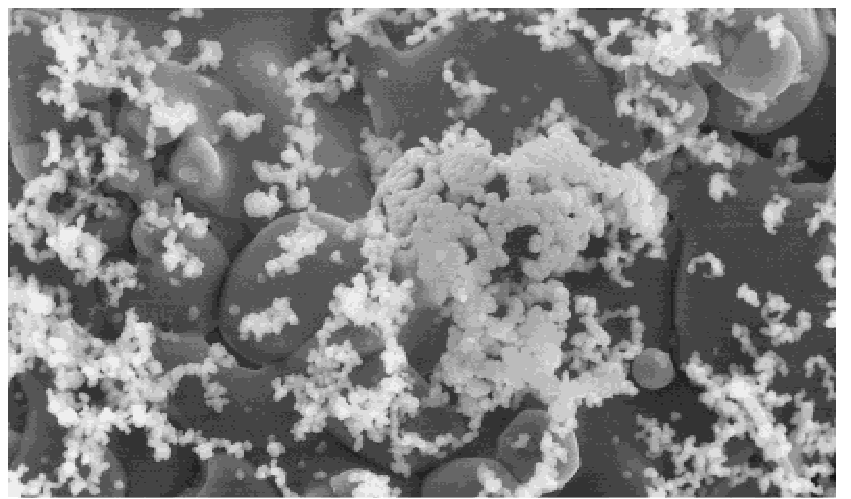

(a)

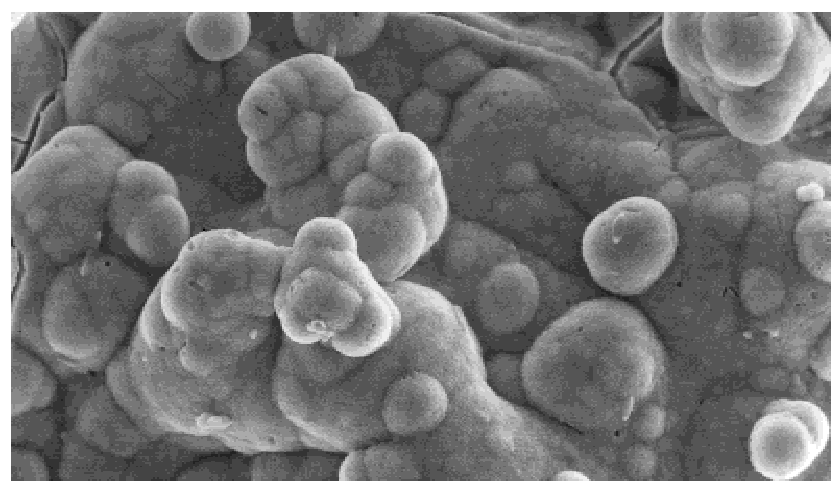

(c)

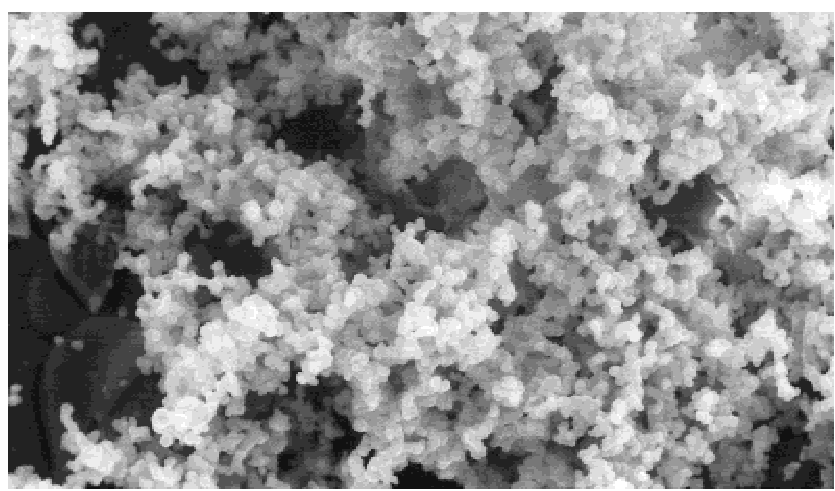

(a)

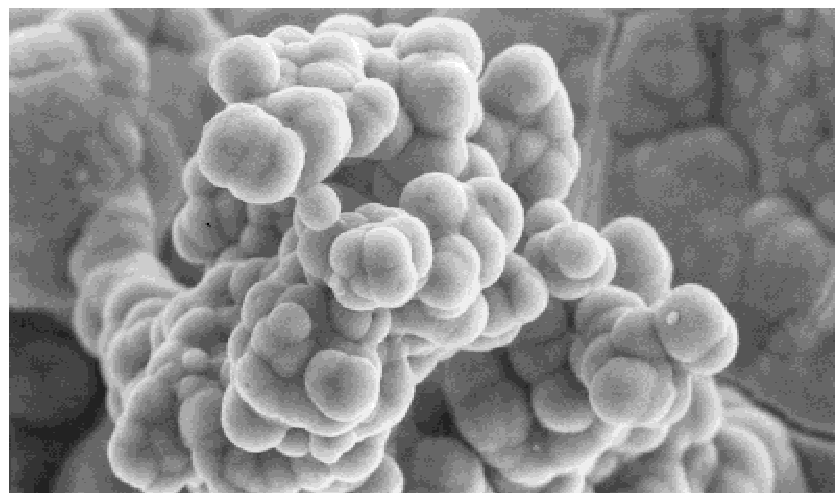

(c)

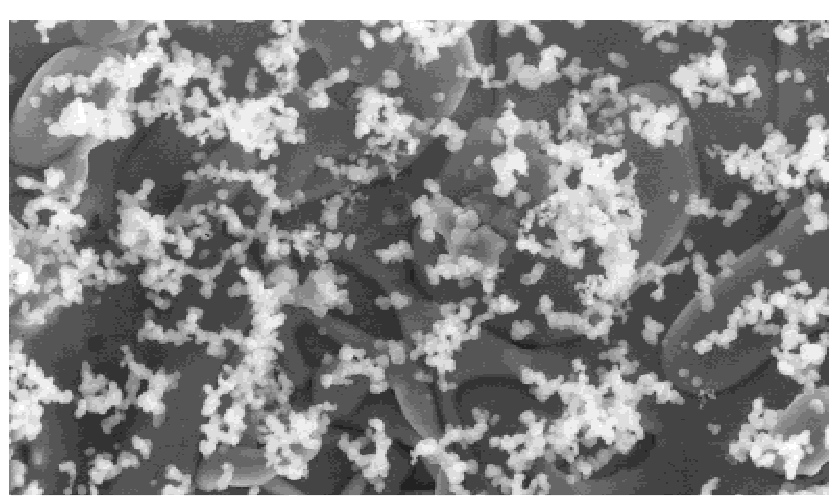

(b)

Figure 4. Changes on the surfaces after 7 days of immersion in SBF. (a) HA; (b) $\mathrm{HA} / \mathrm{G}_{1} 2 \%$ composite; (c) $\mathrm{HA} / \mathrm{G}_{1} 4 \%$ composite (original magnification $\times 2000$ ).

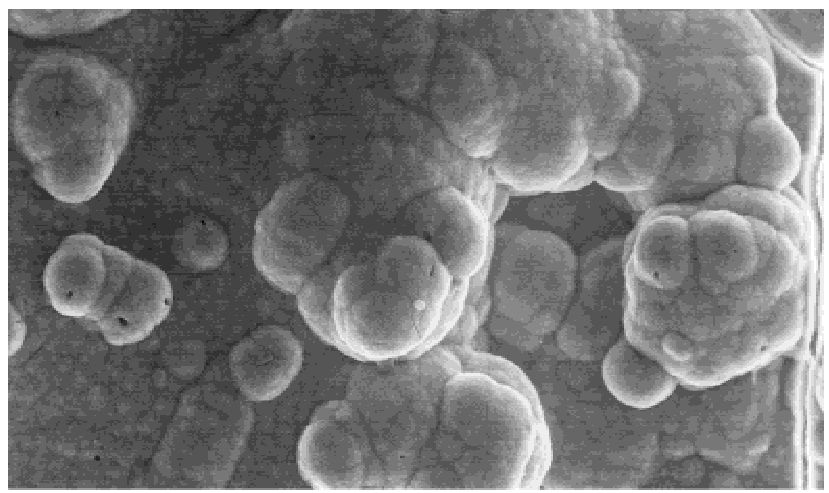

(b)

Figure 5. Changes on the surfaces after 14 days of immersion in SBF. (a) HA; (b) HA/G $12 \%$ composite; (c) $\mathrm{HA} / \mathrm{G}_{1} 4 \%$ composite (original magnification, $\times 2000$ ). 
TABLE IV

Binding Energy of Elements Detected on Surface (eV)

\begin{tabular}{|c|c|c|c|c|c|c|}
\hline \multirow[b]{2}{*}{ Sample } & \multirow{2}{*}{$\begin{array}{l}\text { Immersion Time } \\
\text { (days) }\end{array}$} & \multicolumn{5}{|c|}{ Binding Energy } \\
\hline & & $\mathrm{O}$ & $\mathrm{P}$ & $\mathrm{Ca}$ & $\mathrm{C}$ & $\mathrm{Na}$ \\
\hline \multirow[t]{3}{*}{ HA } & 14 & 531.8 & 133.3 & 347.7 & 285.1 & 1072.8 \\
\hline & 21 & 531.5 & 133.1 & 347.4 & 285.0 & 1072.6 \\
\hline & 60 & 531.3 & 133.1 & 347.1 & 285.0 & 1072.6 \\
\hline \multirow[t]{3}{*}{ Composite HA/G12\% } & 14 & 531.4 & 133.2 & 347.4 & 285.0 & 1072.6 \\
\hline & 21 & 531.5 & 133.1 & 347.1 & 285.1 & 1073.1 \\
\hline & 60 & 531.3 & 133.1 & 347.2 & 285.0 & 1072.6 \\
\hline \multirow[t]{3}{*}{ Composite HA/G14\% } & 14 & 531.5 & 133.2 & 347.5 & 285.0 & 1072.8 \\
\hline & 21 & 531.3 & 133.1 & 347.2 & 285.0 & 1072.4 \\
\hline & 60 & 531.3 & 133.2 & 347.1 & 285.0 & 1072.5 \\
\hline
\end{tabular}

acellular body fluids is a decisive indicator of its bioactivity, since bioactive materials bond to bone in vivo through a similar surface layer. ${ }^{27-31}$ Several techniques have also been used to characterize these CaP-rich layers, particularly thin-film XRD and Fourier transform infrared (FTIR) analysis. ${ }^{32}$ In this work, we compared the Ca-P formation on the surface of novel composite coatings with commercially available HA coating, which was used as a control material.

Calcium and phosphate concentrations in SBF decreased with immersion time as expected, which indicates Ca-P film formation on the surfaces of plasmasprayed coatings. However, the film formation rate was higher for composite coatings than for the simple HA coating, which indicates that there was a faster ionic exchange of calcium and phosphorus between the SBF solution and the composite materials. These results were supported by serial SEM observations. The time required for surface film formation on HA was estimated to be 21 days of immersion in SBF. The $\mathrm{HA} / \mathrm{G}_{1} 2 \%$ composite showed a higher formation rate, and its surface was completely covered after 14 days. The time required for surface film formation on the $\mathrm{HA} / \mathrm{G}_{1} 4 \%$ composite was estimated to be 5 days, showing the highest film formation rate. Therefore, the addition of G1 glass to HA has an important effect on the Ca-P layer formation kinetics. SEM analysis also revealed at magnifications of $\times 2000$ that the Ca-P layer formed on the top surface after immersion was composed of randomly oriented crystallites with a needle-like shape for all coatings. Similar findings were also observed by other authors on sintered HA. ${ }^{29-31}$

Although there have been reports that $\beta$-tricalcium phosphate ( $\beta$-TCP) bonds directly to bone with no formation of an apatite layer, and that this surface layer cannot be reproduced in vitro after immersion in $\mathrm{SBF}^{33}$ Daculsi et al. observed the formation of tiny apatite crystals at the $\beta$-TCP-bone interface. ${ }^{34}$ Some authors have also reported that $\beta$-TCP induces a faster calcium phosphate formation than HA, probably due to its higher solubility. ${ }^{25,34}$ The microstructure of the composite coatings has a biphasic crystalline structure composed of HA and a small amount of $\beta$-TCP phase, as previously reported. ${ }^{35}$ This fact may explain the faster formation of calcium phosphate on the surface of composite coatings.

On the other hand, the glass added to HA for composite preparation, with mainly $\mathrm{Ca}^{2+}$ and $\mathrm{PO}_{4}{ }^{3-}$ in its composition, might play an important role in the apatite formation mechanism, as it is a soluble glass. Since the glass was composed of other ions besides $\mathrm{Ca}$ and $\mathrm{P}$, such as $\mathrm{Na}^{+}, \mathrm{K}^{+}$, and $\mathrm{Mg}^{2+}$, it was not possible to isolate the specific effect of each one. However, Kokubo et al. indicated that magnesium does not have an effect on in vitro apatite formation. ${ }^{36}$

TABLE V

Relative Concentration of Elements Detected on Surface (atm \%)

\begin{tabular}{|c|c|c|c|c|c|c|c|}
\hline \multirow[b]{2}{*}{ Sample } & \multirow{2}{*}{$\begin{array}{c}\text { Immersion Time } \\
\text { (days) }\end{array}$} & \multicolumn{6}{|c|}{ Relative Concentration } \\
\hline & & $\mathrm{O}$ & $\mathrm{P}$ & $\mathrm{Ca}$ & $\mathrm{C}$ & $\mathrm{Na}$ & $\mathrm{Ca} / \mathrm{P}$ \\
\hline \multirow[t]{3}{*}{ HA } & 14 & 48.2 & 12.7 & 18.5 & 19.7 & 0.815 & 1.5 \\
\hline & 21 & 43.1 & 12.4 & 18.4 & 25.7 & 0.490 & 1.5 \\
\hline & 60 & 41.6 & 8.7 & 11.6 & 31.0 & 0.218 & 1.3 \\
\hline \multirow[t]{3}{*}{ Composite HA/G12\% } & 14 & 45.4 & 13.8 & 18.4 & 22.4 & 0.325 & 1.3 \\
\hline & 21 & 45.1 & 12.6 & 18.0 & 23.4 & 0.960 & 1.4 \\
\hline & 60 & 39.6 & 6.4 & 8.9 & 41.5 & 0.083 & 1.4 \\
\hline \multirow[t]{3}{*}{ Composite HA/G14\% } & 14 & 49.1 & 14.2 & 18.8 & 16.8 & 1.138 & 1.3 \\
\hline & 21 & 46.5 & 12.3 & 16.7 & 23.7 & 0.733 & 1.4 \\
\hline & 60 & 40.6 & 6.4 & 9.0 & 43.3 & 0.710 & 1.4 \\
\hline
\end{tabular}




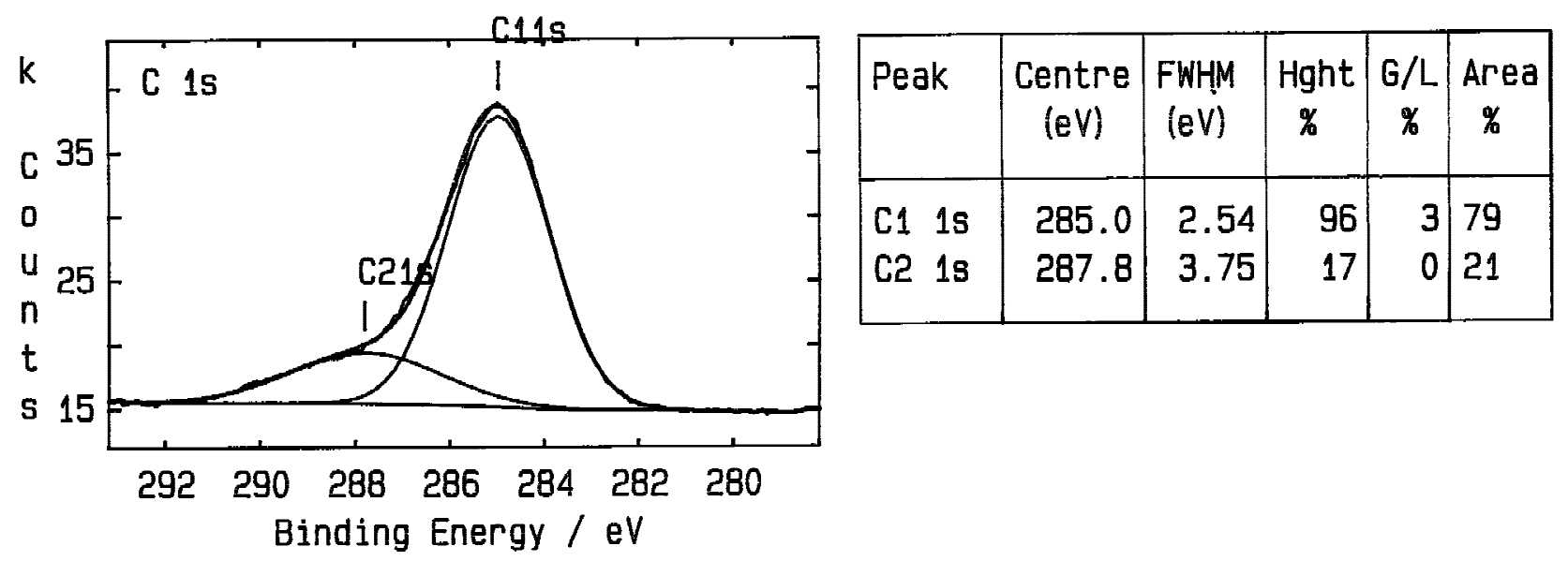

Figure 6. The deconvolution of $\mathrm{C} 1$ s revealed two peaks, at $285.0 \pm 0.1 \mathrm{eV}$ and $287.8 \pm 0.2 \mathrm{eV}$.

For all coatings, a three-stage phenomenon may be distinguished: (a) an initial period where ionic exchange between materials surface and the solution was slow, which should correspond to the incubation time for the apatite formation; followed by (b) an intermediate stage with a very high Ca-P film formation rate; and (c) a final stage where film formation tended to slow down. As the equilibrium state was achieved very slowly, this final stage may have been related to the decrease in solution supersaturation. Identical behavior may be inferred from other analyses performed using similar bioactive materials. ${ }^{25}$

X-ray photoelectron spectroscopic results showed that the chemical characteristics of these layers did not seem to be influenced by the presence of G1 glass, as the peak positions of all detected elements that composed the Ca-P-rich layer and their relative atomic concentration were practically the same for HA and for composites coatings, as presented in Tables IV and $\mathrm{V}$.

The reference for XPS binding energy data was the adventitious $\mathrm{C} 1 \mathrm{~s}$ peak at $285.0 \mathrm{eV}$. The peaks positions of all detected elements were corrected with respect to this $\mathrm{C} 1 \mathrm{~s}$ level. The binding energies determined for P2p, Ca2p3, and O1s obtained at 133.1, 347.2, and $531.3 \mathrm{eV}$ respectively corresponded to the HA compound, as they all agreed with the standard binding energies for HA listed in the NIST XPS database. ${ }^{37}$ However, this apatite was nonstoichiometric, as its $\mathrm{Ca} / \mathrm{P}$ ratio was much lower than 1.67 , which corresponds to stoichiometric HA. Several authors have obtained the same calcium-deficient apatite layers with various bioactive materials. ${ }^{38,39}$ After $\mathrm{C} 1$ s peak deconvolution, using a Gaussian fitting procedure, it was possible to detect a peak at $287.8 \mathrm{eV}$ which corresponded to $\mathrm{CO}_{3}{ }^{2-}$ on the surface layer. ${ }^{40}$ The incorporation of $\mathrm{CO}_{3}{ }^{2-}$ in the $\mathrm{HA}$ structure should be attributed to the ionic concentration of SBF, since it contains $\mathrm{HCO}_{3}{ }^{-}$(Table III). It is therefore possible to conclude that this surface layer is a calcium-deficient carbon- ated HA, with a structure similar to that formed on bioactive materials when implanted in vivo. Other authors have reported the presence of carbonated apatite layers on biomaterials surface after immersion in physiological solutions, although using different analysis techniques, such as FTIR. ${ }^{28-32}$

\section{CONCLUSION}

A Ca,P surface layer was formed on the surface of the various coatings. Serial SEM observation indicated a faster film formation on the composite's surface than on HA, currently leading to increased bioactivity. $\mathrm{HA} / \mathrm{G}_{1} 4 \%$ composite showed the fastest film formation rate. Atomic absorption spectroscopic analysis of the solutions confirmed the adsorption of calcium and phosphate onto the coatings, with this adsorption taking place earlier in the case of composite materials than in HA. XPS analysis allowed for precise determination of its chemical composition, revealing that this layer was a calcium-deficient carbonated HA with an average $\mathrm{Ca} / \mathrm{P}$ ratio ranging from 1.3 to 1.4 and containing carbonate ions, $\mathrm{CO}_{3}{ }^{2-}$, in its structure.

\section{References}

1. Denissen H, Mangano C, Venini G, editors. Hydroxylapatite implants. Padua: Piccin Nuova Libraria, S.P.A., 1985.

2. Van Raemdonck W, Ducheyne P, De Meester P. Calcium phosphate ceramics. In: Ducheyne P, Hastings GW, editors. Metal and ceramic biomaterials. Boca Raton, FL: CRC Press, 1984. p 143-166.

3. Legeros RZ. Incorporation of magnesium in synthetic and biological apatites. In: Fearnead RW, editor. Tooth enamel IV. Amsterdam: Elsevier Science, 1994. p 32-36.

4. Jha LJ, Best SM, Knowles JC, Rehman I, Santos JD, Bonfield W. Preparation and characterization of fluoride-substituted apatites. J Mater Sci Mater Med 1997;8:185-191. 
5. Geesink RGT, deGroot K. Chemical implant fixation using hydroxyl-apatite coatings. Clin Orthop 1987;2:147-170.

6. Radin S, Ducheyne P. The effect of plasma sprayed induced changes in the characteristics on the in vitro stability of calcium phosphate ceramics. In: Transactions of the 16th annual meeting of the Society for Biomaterials XIII; 1990. p 128-130.

7. Cook SD, Thomas KA. Hydroxyapatite coated porous titanium for use as an orthopaedic biologic attachment. Clin Orthop 1989;230:303-312.

8. McPherson R, Gane N, Bastow TJ. Structural characterization of plasma-sprayed hydroxylapatite coatings. J Mater Sci Mater Med 1995;6:327-334.

9. de Groot K, Geesink R, Klein CPAT, Serekian P. Plasma sprayed coatings of hydroxylapatite. J Biomed Mater Res 1987; 21:1375-1381.

10. Ravagliolli A, Krajewszki A, Laudadio P, Presutti L, Cunsolo E, Martinetti R. About ceramics for stapedial prostheses and the ossicular chain. In: Yamamuro T, Kokubo T, Nakamura T, editors. Fifth International Symposium on Ceramics in Medicine-Bioceramics 5. Kyoto: Kobunshi Kankokai; 1992. p 451458.

11. Hastings GW, Daily D. Hydroxyapatite coatings. In: Oonishi $\mathrm{H}$, Aoki H, Sawai K, editors. First International Symposium on Ceramics in Medicine-Bioceramics 1. Tokyo: Ishiyaku EuroAmerica; 1989. p 355-358.

12. Aoki H. Medical applications of hydroxyapatite. In: Aoki $\mathrm{H}$, Sawai K, editors. Science and medical applications of hydroxyaptite. Tokyo: Takyama Press System Centre; 1991. p 175-192.

13. Rey C. Calcium phosphate biomaterials and bone mineral: Differences in composition, structures and properties. Biomaterials 1990;11:13-15.

14. Evans G, Behiri J, Currey J, Bonfield W. Microhardness and Young's modulus in cortical bone exhibiting a wide range of mineral volume fractions, and in a bone analogue. J Mater Sci Mater Med 1990;1:38-43.

15. Rey C, Froche M, Heughebaert M, Heughebaert JC, Lacout JL, Vignoles M. Apatite chemistry in biomaterial preparation, shaping and biological behaviour. In: Bonfield W, Hastings GW, Tanner KE, editors. Fourth International Symposium on Ceramics in Medicine-Bioceramics 4. London: ButterworthHeinemann; 1991. p 57-60.

16. Knowles JC, Talal S, Santos JD. Sintering effects in a glass reinforced hydroxyapatite. Biomaterials 1996;17:1437-1442.

17. Kokubo T, Hayashi T, Sakka S, Kitsugi T, Yamamuro T, Takagi M, Shibuya T. Surface structure of a load bearable bioactive glass-ceramic A-W. In: Vicenzini P, editor. High Tech Ceramics. Amsterdam: Elsevier Science Publisher BV; 1981. p 175184.

18. Hench L, Anderson OH, LaTorre GP. The kinetics of bioactive ceramics. Part III: Surface reactions for bioactive glasses compared with inactive glass. In: Bonfield W, Hastings GW, Tanner KE, editors. Fourth International Symposium on Ceramics in Medicine-Bioceramics 4. London: Butterworth-Heinemann; 1991. p 155-162.

19. Daculsi G, LeGeros RZ, Heughebart M, Barbieux I. Formation of a carbonate apatite crystals after implantation of calcium phosphate ceramics. Calcif Tissue Int 1990;46:20-27.

20. Kokubo T, Ito S, Huang ZT, Hayashi T, Sakka S, Kitsugi T, Yamamuro T. Ca-P rich layer formed on high strength bioactive glass-ceramic A-W. J Biomed Mater Res 1990;24:331-343.

21. Ducheyne P, Radin S, Ishikawa K, Kim CS. In vivo dissolution and precipitation of calcium phosphate phases on biomaterials correlates with in vivo bioactivity. In: Bonfield W, Hastings GW, Tanner KE, editors. Fourth International Symposium on Ceramics in Medicine-Bioceramics 4. London: ButterworthHeinemann; 1991. p 135-144.

22. Rey C, Hina A, Amrah-Bouali S, Ranz X. Surface reactions of calcium-phosphate bioceramics, comparison with bone min- eral surface chemistry. In: Ravaglioli A, editor. Fourth Euro Ceramics. Vol. 8. Faenza: Gruppo Editoriale Faenza Editrice; 1995. p 301-312.

23. van Blitterswijk CA, Grote JJ, Kuypers W, Blok-van Hoek CJG, Daems WT. Bioreactions at the tissue/hydroxyapatite interface. Biomaterials, 1985;6:243-251.

24. Ducheyne P. Bioceramics: Material characteristics versus in vivo behavior. J Biomed Mater Res 1987;21:219-236.

25. Hyakuna K, Yamamuro T, Kotoura Y, Oka M, Nakamura T, Kitsogi T, Kokubo T, Kushitani H. Surface reactions of calcium phosphate ceramics to various solutions. J Biomed Mater Res 1990;24:471-488.

26. Santos JD, Reis RL, Monteiro FJ, Knowles JC, Hastings GW. Liquid phase sintering of hydroxyapatite by phosphate and silicate glass additions: Structure and properties of the composites. J Mater Sci Mater Med 1995;6:348-352.

27. Tanahashi M, Yao T, Kokubo T, Minoda M, Miyamoto T, Nakamura T, Yamamuro T. Apatite coated on organic polymers by biomimetic process: improvement in adhesion to substrate by $\mathrm{HCl}$ treatment. J Mater Sci Mater Med 1995;6:319-326.

28. Neo M, Nakamura T, Yamamuro T, Ohtsuki C, Kokubo T, Bando Y. A comparative study of ultrastructures of the interfaces between four kinds of surface-active ceramic and bone. J Biomed Mater Res 1992;26:1419-1432.

29. Li P, Ohtsuki C, Kokubo T, Nakanishi K, Soga N, Nakamura T, Yamamuro T. Process of formation of bone-like apatite layer on silica gel. J Mater Sci Mater Med 1993;4:127-131.

30. Santos JD, Jha LJ, Monteiro FJ. Surface modifications of glassreinforced hydroxyapatite composites. Biomaterials 1995;16: 521-526.

31. Neo M, Kotani S, Fujita Y, Yamamuro T, Bando Y, Ohtsuki C, Kokubo T. Differences in ceramic-bone interface between surface-active ceramics and resorbable ceramics: A study by scanning and transmission electron microscope. J Biomed Mater Res 1992;26:255-267.

32. Li P, Yang Q, Zhang F, Kokubo T. The effect of residual glassy phase in a bioactive glass-ceramic on the formation of its surface apatite layer in vitro. J Mater Sci Mater Med 1992;3:452456.

33. Kotani S, Fujita Y, Kitsugi T, Nakamura T, Yamamuro T. Bone bonding mechanism of $\beta$-tricalcium phosphate. J Biomed Mater Res 1991;25:1303-1315.

34. Daculsi G, LeGeros RZ, Heughebaert M, Barbieux I. Formation of carbonate-apatite crystals after implantation of calcium phosphate ceramics. Calcif Tissue Int 1990;46:20-27.

35. Silva PL, Monteiro FJ, Santos JD, Knowles JC. Adhesion and microstructural characterisation of plasma sprayed hydroxyapatite-glass ceramic coatings onto Ti-6Al-4V substrates. Surf Coatings Technol 1998;102:191-196.

36. Kokubo T, Kushitani H, Ohtsuki C, Sakka S, Yamamuro T. Chemical reaction of bioactive glass and glass-ceramics with a simulated body fluid. J Biomed Mater Res 1992;3:79-83.

37. Blakeslee DM, Dal-Favero ME. NIST X-ray photoelectron spectroscopy database. Gaitherburg, MD: National Institute of Standards and Technology, 1997.

38. Anderson $\mathrm{OH}, \mathrm{Kangasniemi}$ I. Calcium phosphate formation at the surface of bioactive glass in vitro. J Biomed Mater Res 1991;25:1019-1030.

39. Santos JD, Jha LJ, Monteiro FJ. In vitro calcium phosphate formation on $\mathrm{SiO}_{2}-\mathrm{Na}_{2} \mathrm{O}-\mathrm{CaO}-\mathrm{P}_{2} \mathrm{O}_{5}$ glass reinforced hydroxyapatite composite: A study by XPS analysis. J Mater Sci Mater Med 1996;7:181-185.

40. Verhoeven JAT, Van Doveren H. An XPS investigation of the interface of methane, ethyne, ethene and ethane with barium surface. Surf Sci 1982;123:369-383. 